\title{
Peran Youtuber dengan Penonton dalam Menjalankan Gaya Hidup Sehat New Normal (Studi Kasus Youtuber Shiely Venessa)
}

\author{
Jesvanny ${ }^{1}$, Riris Loisa $^{2 *}$, Sisca Aulia ${ }^{3}$ \\ ${ }^{1}$ Fakultas Ilmu Komunikasi, Universitas Tarumanagara \\ Email: jesvanny.915170096@stu.untar.ac.id \\ ${ }^{2}$ Fakultas Ilmu Komunikasi, Universitas Tarumanagara \\ Email: ririsl@fikom.untar.ac.id \\ ${ }^{3}$ Fakultas Ilmu Komunikasi, Universitas Tarumanagara \\ Email: siscaa@fikom.untar.ac.id
}

Masuk tanggal : 15-12-2021, revisi tanggal :06-01-2022, diterima untuk diterbitkan tanggal : 16-01-2022

\begin{abstract}
The development in the 4.0 industrial revolution resulted in the internet developing rapidly, so that the application of technology has spread throughout all sectors. This was coupled with the Covid-19 pandemic, and made changes in the pattern of people's lives in Indonesia which led to an increase in internet users in Indonesia to 175.4 million million or it can be said that $50 \%$ of the total population of Indonesia. And the social media that is in the spotlight is Youtube so it is used in this study. The purpose of this study is to determine whether there is a role for Youtuber and the audience in carrying out a new normal healthy lifestyle. The research method used in this research is qualitative with data collection techniques in the form of observation and interviews with YouTubers and Subscribers, and with the aim of knowing whether there is a Youtuber role with the audience in carrying out a new normal healthy lifestyle. The results of the study show that YouTubers are very interested in creating content about this new normal healthy lifestyle and Subscribers and Viewers provide good comments and responses with new normal healthy lifestyle content.
\end{abstract}

Keywords: healthy lifestyle, new normal, youtuber

\begin{abstract}
Abtrak
Perkembangan dalam revolusi industri 4.0 mengakibatkan internet berkembang dengan pesat, hingga penerapan teknologi pun telah menyebar di seluruh sektor. Hal ini ditambah dengan pandemi Covid-19 yang membuat perubahan dalam pola hidup masyarakat Indonesia. Pengguna internet di Indonesia melonjak hingga 175,4 juta jiwa atau dapat dikatakan 50\% dari total penduduk Indonesia. Penggunaan media sosial juga melonjak salah satunya Youtube. Penelitian ini ingin mengetahui ada tidaknya peran youtuber dengan penonton dalam menjalankan gaya hidup sehat new normal. Metode penelitian yang digunakan dalam penelitian ini adalah kualitatif dengan teknik pengumpulan data berupa observasi dan wawancara dengan youtuber dan pelanggan (subscriber), dan dengan tujuan untuk mengetahui ada tidaknya peran youtuber dengan penonton dalam menjalankan gaya hidup sehat new normal. Hasil dari penelitian menunjukan bahwa para youtuber sangat tertarik untuk membuat konten tentang gaya hidup sehat new normal, subscriber dan penonton (viewer) memberikan komentar dan tanggapan yang baik dengan konten gaya hidup sehat new normal.
\end{abstract}

Kata Kunci: gaya hidup sehat, new normal, youtuber 


\section{Pendahuluan}

Perkembangan dalam revolusi industri 4.0 terutama berbasis pada internet semakin meningkat. Penerapan teknologi pun telah tersebar di seluruh sektor maupun bidang dalam kehidupan sehari-hari. Menurut Ahmad (2011) perkembangan dalam penggunaan media internet semakin pesat setelah internet dengan mudah diakses melalui smartphone, dimana di dalam smartphone berisi fitur dan fasilitas yang menarik. Pengguna internet di Indonesia selalu mengalami peningkatan setiap tahunnya pada tahun 2020 pengguna internet mencapai 175,4 juta sehingga dikatakan lebih dari $50 \%$ dari total penduduk Indonesia yang berjumlah 272,1 juta jiwa (Hootsuite, 2020). Hal ini ditambah dengan adanya pandemi Covid-19, selama beberapa bulan ini. Pandemi telah mengubah pola kehidupan masyarakat di Indonesia dan perubahannya juga terjadi di berbagai bidang.

Menurut Anne (2016) bahwa gaya hidup sehat merupakan gaya hidup yang lebih memperhatikan faktor yang dapat mempengaruhi kesehatan seperti makanan dan juga olahraga. Dengan menerapkan gaya hidup sehat sehari-hari maka akan berpengaruh juga kepada tingkat kesehatan seseorang (Anne, 2016). Menurut Soenarjo (2015) bahwa terdapat faktor yang mempengaruhi gaya hidup sehat, yaitu : kebersihan diri, makanan yang sehat, dan olahraga serta gerak secukupnya.

Menurut Heru Suprihadi (2017) terdapat beberapa dimensi dari gaya hidup sehat, yaitu: pertama adalah aktivitas, dapat berbentuk kerja, anggota perkumpulan, acara sosial dan lainnya. Kedua adalah ketertarikan, merupakan suatu tindakan yang memiliki perhatian secara terus menerus. Dan terakhir adalah pendapat, dalam hal ini berkaitan dengan respon seseorang terhadap situasi yang terjadi baik yang tertulis maupun secara lisan.

Dalam kondisi pandemi, pemerintah menerapkan aturan normal baru (new normal). New normal merupakan suatu kebijakan yang dibuat oleh pemerintah dalam rangka pasca pemulihan berbagai sektor yang sebelumnya berhenti secara sementara dikarenakan adanya pandemi Covid-19. Dalam hal in kebijakannya tetap menerapkan protokol kesehatan dan pemerintah memaksimalkan penerapan jaga jarak (Nasution, 2020).

Salah satu dampak yang terbesar dalam pandemi ini yaitu perubahan masyarakat dalam penggunaan media sosial. Media sosial merupakan suatu wadah yang fokusnya pada eksistensi para pengguna nya untuk melakukan segala aktivitas dan kegiatan. Maka dari itu, kini media sosial dapat digunakan sebagai penghubung atau dapat dikatakan sebagai fasilitator yang dilakukan secara online yang berfungsi memperkuat hubungan antar penggunanya serta ikatan dapat terjalin (Puspita Yesi, 2015). Selain itu, media sosial juga dapat diartikan sebagai tempat penggunanya dapat saling melakukan interaksi dengan pengguna lain dan nantinya akan terbentuk suatu ikatan secara virtual (Nasrullah, 2016).

Youtube merupakan suatu situs yang berbentuk web video sharing dan penggunanya dapat melakukan kegiaatan seperti menonton, berbagi video, mengunggah video, dan lainnya (Tjanatjantia, 2015). Youtube didirikan pada tahun 2005 oleh beberapa mantan karyawan Paypal, yaitu Chad, Steve, dan Jawed. Pada aplikasi ini, pengguna nya dapat meng-upload video dan dapat disaksikan oleh pengguna lainnya di seluruh dunia. Menurut pendapat Faiqah (2017) terdapat beberapa manfaat dalam penggunaan aplikasi Youtube, yaitu (1) Adanya layanan secara gratis; (2) Dapat melakukan download video tertentu; (3) Saling berbagi informasi antar pengguna; (4) Dapat digunakan sebagai pengenalan dan pemasaran 
produk; (5) Mendukung industri hiburan; (6) Melakukan branding suatu lembaga maupun institusi; (7) Mengetahui adanya respon berbentuk komentar dari viewers.

Youtuber bisa dikatakan sebagai orang yang mempunyai suatu channel pada Youtube yang digunakan untuk menghasilkan pendapatan dan juga eksistensi (Ramadhan, 2018). Para youtuber berlomba-lomba memiliki banyak subscriber karena semakin banyak subscriber yang berlangganan pada channel tersebut maka akan berpengaruh pada pendapatan dan juga popularitas mereka.

Saat pandemi, pengguna membutuhkan media sosial untuk mencari informasi dan pengetahuan mengenai kejadian di sekitar. Youtuber sangat berperan dalam hal ini, dimana pengguna Youtube cukup banyak dan terdapat beragam konten positif yang mudah untuk diakses. Pada saat pandemi, Youtube mengalami peningkatan yang pesat. Oleh karena itu peneliti mengangkat topik "Peran Youtuber dengan Penonton dalam Menjalankan Gaya Hidup Sehat New Normal", untuk mengetahui ada tidaknya peran youtuber dengan penonton dalam menjalankan gaya hidup sehat new normal dengan harapan dapat berguna bagi pengguna Youtube dalam mengambil keputusan untuk menjalankan gaya hidup sehat new normal saat pandemi, khususnya juga dalam bidang Ilmu Komunikasi.

\section{Metode Penelitian}

Peneliti menggunakan pendekatan kualitatif yang merupakan penelitian yang menekankan makna, konsep, gejala, karakteristik mengenai suatu fenomena dengan berbagai cara yang disajikan secara naratif (Yusuf, 2015). Metode penelitian yang digunakan yaitu studi kasus. Peneliti studi kasus berupaya menelaah sebanyak mungkin data mengenai subjek yang diteliti. Metode penelitian dengan studi kasus merupakan model yang fokusnya pada suatu pengembangan dari adanya sistem namun terbatas dari kasus yang dianalisis dan dijelaskan secara detail dan lengkap dengan bantuan dari bermacam-macam sumber informasi dengan data yang kredibel dan relevan secara lengkap. Dapat dilakukan dengan wawancara atau pengamatan yang mendalam oleh si peneliti

Pada penelitian kualitatif, dalam subyek penelitiannya biasa disebut dengan informan yang berfungsi untuk memberikan informasi yang berhubugan dengan penelitian. Dalam hal ini, teknik untuk menentukan informan menggunakan teknik purposive sampling, yang artinya peneliti menentukan karakteristik yang mencakup orang-orang berdasar kriteria tertentu dan berdasar oleh tujuan penelitian skripsi (Sugiyono, 2014). Dari data informan menggunakan para youtuber dan subscribernya dikarenakan saling memanfaatkan fitur Youtube baik untuk menonton maupun membuat konten mengenai gaya hidup sehat new normal.

Dalam penelitian ini menjadikan data primer sebagai untuk memperoleh suatu informasi tentang peran youtuber dengan penonton dalam menjalankan gaya hidup sehat new normal. Dengan adanya data primer dapat digunakan sebagai pendukung hasil penelitian. Untuk pengambilan data sekunder melalui observasi dan wawancara, tentang peran dan hubungan antara youtuber dengan penonton dalam menjalankan gaya hidup sehat new normal.

\section{Hasil dan Pembahasan}

Setelah mendapatkan informasi yang dibutuhkan melalui observasi dan wawancara, peneliti mendapatkan hasil penelitian yaitu melalui media sosial 
Youtube yang merupakan situs berbentuk web video sharing. Sebagian besar informan mengatakan bahwa selama berada di rumah selama enam bulan dan itu membuat cukup bosan dan malas untuk berolahraga dan menjalankan aktivitas lainnya, terlebih saat adanya pandemi cukup aktif beraktivitas di luar rumah. Dengan adanya new normal sangat terbantu dalam beraktivitas di luar rumah walaupun terkadang masih khawatir tertular virus, namun dengan menerapkan protokol kesehatan yang baik, maka akan meminimalisir risiko tertular virus tersebut.

Saat new normal, menerapkan protokol kesehatan setiap hari dalam beraktivitas diluar rumah itu adalah suatu keharusan dan wajib karena dapat menjaga kesehatan diri sendiri maupun kesehatan orang lain agar terhindar dari penularan virus corona. Dalam penerapan protokol kesehatan itu wajib dilakukan pada setiap orang yang keluar rumah, hal ini juga berlaku pada orang yang di dalam rumah untuk selalu cuci tangan dengan sabun dan membatasi kontak fisik secara langsung. Terlebih virus corona sangat mudah menular.

Setelah dilakukan wawancara dengan informan bahwa kebijakan new normal sangat membantu dalam beraktivitas kembali namun tetap terbatas dan masih belum berani berlama-lama beraktivitas di luar terlebih dalam tempat yang banyak orang dan kerumunan seperti mall dan tempat umum lainnya. Namun kebijakan new normal sangat membantu dalam beraktivitas kembali. Walaupun kebijakan new normal telah diterapkan agar masyarakat dapat beraktivitas kembali, namun masyarakat juga jangan lengah dan tetap mematuhi protokol kesehatan yang berlaku. Menghadapi kondisi new normal, kita harus lebih ekstra dalam menjaga kesehatan tubuh seperti selalu memakai masker saat beraktivitas di luar rumah. Kebijakan new normal sangat membantu penulis dalam beraktivitas kembali, namun tidak semua orang bisa beraktivitas seperti semula

Seorang youtuber memiliki channel yang di dalamnya berisikan kontenkonten miliknya seperti vlog, tips and trick video tutorial, review dan lainnya. Konten ini dipilih oleh youtuber untuk memperkenalkan sisi kreativitas dari dirinya. Setelah dilakukan wawancara dengan pemilik akun Youtube, terdapat alasannya dari youtuber tersebut dalam membuat konten di Youtube. Melalui Youtube setiap orang memiliki kebebasan dalam hal penyampaian pendapat, berdialog secara terbuka, berkreasi dan bertujuan untuk mengetahui informasi tertentu terutama konten dalam hal gaya hidup sehat saat new normal yang sangat bermanfaat dan para youtuber dapat mengajak para viewer-nya untuk ikut serta dalam hal positif tersebut demi kesehatan kita bersama. Dengan adanya konten Youtube mengenai pentingnya gaya hidup sehat saat new normal ini diharapkan dapat menjadi sarana edukasi dan pengingat masyarakat untuk tetap waspada dengan adanya virus corona. Terlebih saat ini, masyarakat lebih mudah menerima informasi melalui sosial media, tepatnya melalui Youtube.

Youtuber mengungkapkan bahwa dia tertarik untuk membuat konten gaya hidup sehat karena saya menikmati dan memang tertarik membuat konten ini terus menerus. Dengan hidup sehat maka akan mengajak orang lain untuk melakukan aktivitas ataupun kegiatan yang bersifat observable maupun yang tidak dimana berkaitan mengenai peningkatan terhadap kesehatan individu dan pemeliharaan kesehatan yang di dalam nya termasuk pencegahan dan perlindungan diri.

Para youtuber juga ingin memberikan dampak positif pada penonton, terutama pada subscriber setia yang telah mengikuti konten saya hingga sekarang. Selain itu juga memiliki perhatian secara terus menerus dan ketertarikan untuk mengajak viewer dan subscriber untuk gaya hidup sehat saat new normal. 
Jawaban yang dikemukakan oleh informan bahwa dengan konten Youtube mengenai gaya hidup sehat new normal berpengaruh terhadap penerapan kegiatan sehari-harinya, karena sadar dalam hal menjaga kesehatan diri di tengah pandemi corona ini dan konten tersebut mampu memberikan dampak positif terhadap diri sendiri maupun orang lain yang menonton. Dengan kebijakan new normal awalnya cukup bingung apa saja yang harus dilakukan, setelah menonton konten Youtube mengenai gaya hidup sehat new normal, terpengaruh untuk mengikuti tips dan trik nya dalam hal apa saja yang perlu dipersiapkan dan bagaimana menjalani gaya hidup sehatnya. Adapun harapan dari para subscriber dan viewer dengan adanya gaya hidup sehat new normal ini, masyarakat dapat lebih bersosialisasi dan tetap menjaga kesehatan agar terhindar dari virus corona dengan menerapkan protokol kesehatan. Selain itu, harapan dengan adanya gaya hidup sehat new normal ini, menjadi awal langkah baru untuk beraktivitas yang sebelumnya sempat terkendala dikarenakan pandemi virus corona, sehingga dengan adanya kebijakan new normal untuk kedepannya masyarakat dapat beradaptasi dengan kondisi yang ada dan semoga kasus pandemi corona di Indonesia cepat berakhir.

Berdasarkan dengan hasil kajian yang didasarkan pada hasil wawancara dan observasi menggambarkan bahwa pada variabel aktivitas (activity) dalam hal ini, aktivitas dapat berbentuk kerja, anggota perkumpulan, acara sosial, dan lainnya dalam kehidupan sehari-hari seseorang. Saat peneliti melakukan observasi dan wawancara kepada informan mengenai aktivitas saat adanya new normal sangat terbatas, semua informan mengatakan hal yang hampir mirip karena nyatanya kegiatan masih dibatasi dengan menerapkan protokol kesehatan yang harus dipatuhi. Dalam hal ini, dapat dikatakan bahwa masyarakat telah sadar untuk menerapkan protokol kesehatan setiap hari dalam beraktivitas di luar rumah, yang dijabarkan dengan beberapa variabel sebagai berikut:

1. Variabel Ketertarikan (interest)

Semua informan mengatakan tertarik untuk membuat konten gaya hidup sehat dalam langka menyebarkan informasi dan mengajak penontonnya untuk menerapkannya juga dalam kehidupan sehari-harinya. Keduanya yaitu youtuber dan subscriber memiliki perhatian pada konten mengenai gaya hidup new normal kebiasaan serta perilaku yang beradaptasi terhadap membudayakan perilaku yang bersih dan sehat seperti melakukan cuci tangan, penggunaan masker, dan menghindari kerumunan.

2. Variabel Pendapat (opini)

Hasil wawancara kepada informan menyebutkan bahwa pendapat yang disalurkan melalui komentar yang diberikan oleh subscriber dan viewer di Youtube-nya cukup positif dan mendukung dalam pembuatan kontennya, terdapat beberapa komen yang diajukan untuk memperjelas informasi yang telah diberikan. Selain itu komentar secara langsung melalui akun Youtube, sebagian besar subscriber dan penontonnya terpengaruh dengan konten akun youtuber tersebut.

\section{Kesimpulan}

Selama beberapa bulan ini, pandemi corona telah mengubah pola kehidupan masyarakat di Indonesia dan perubahannya juga terjadi di berbagai bidang seperti ekonomi, sosial, bisnis, politik dan lain sebagainya. Pada saat new normal pandemi Covid-19 yang dalam prakteknya harus mempunyai dukungan berbagai macam sektor, tak terkecuali pada penggunaan media sosial, salah satunya yaitu Youtube 
yang memberikan informasi yang positif dan bermanfaat untuk mendukung gaya hidup sehat new normal.

Hasil penelitian yang didasarkan pada hasil wawancara menggambarkan bahwa variabel aktivitas, dapat dikatalan bahwa masyarakat telah sadar untuk menerapkan protokol kesehatan setiap hari dalam beraktivitas di luar rumah. Pada variabel ketertarikan (interest), semua informan mengatakan tertarik untuk membuat konten gaya hidup sehat dalam langka menyebarkan informasi dan mengajak penontonnya untuk menerapkannya juga dalam kehidupan sehari-harinya.

Selanjutnya pada variabel pendapat (opini), biasanya permasalahan tersebut dapat dilihat dari adanya perbedaan-perbedaan cara berperilaku saat berkomunikasi baik antara youtuber dengan subscriber, maupun hal sebaliknya. Namun hasil wawancara kepada informan menyebutkan bahwa pendapat yang disalurkan melalui komentar yang diberikan oleh subscriber dan viewer di Youtube cukup positif dan mendukung dalam pembuatan kontennya. Maka dari itu, dikatakan konten Youtube dapat mempengaruhi para audiens. Berdasarkan hasil penelitian yang telah dilakukan, hasilnya bahwa konten Youtube dapat mempengaruhi pengetahuan dan opini audiensnya.

\section{Ucapan Terima Kasih}

Penulis mengucapkan terima kasih kepada seluruh pihak yang telah membantu dalam pembuatan jurnal penelitian ini.

\section{Daftar Pustaka}

A. Muri Yusuf. 2014. "Metode Penelitian Kuantitatif, Kualitatif \& Penelitian. Gabungan". Jakarta: Prenadamedia Group

Atmajanti, C. I., Richtiara, G. C., Az-Zahra, D., Sophia, N. A., \& Rahmawati, P. A. (2020). Edukasi Protokol Kesehatan New Normal dan Pengenalan Dunia Bisnis di Tengah Pandemi Covid-19 Melalui Media Sosial. Jurnal Layanan Masyarakat (Journal of Public Services), 4(2), 472-478.

Hootsuite (2 Oktober 2020). Data Pengguna Internet dan Sosial Media di Indonesia Diakses dari https://andi.link/hootsuite-we-are-social-indonesian-digital-report2020/

Hootsuite (2 Oktober 2020). Platforms Media Sosial Teraktif. Diakses dari https://andi.link/hootsuite-we-are-social-indonesian-digital-report-2020/

Heru. Suprihadi. (2017). Pengaruh Kualitas pelayanan dan Gaya. Hidup Sehat Terhadap Keputusan Pembelian. Cafe Jalan Korea.

Nanggala, A. (2020). Peran Generasi Muda Dalam Era New Normal. Widya Wacana: Jurnal Ilmiah, 15(2), 81-92.

Puspita Yesi, 2015, 'Pemanfaatan New Media dalam Komunikasi, Jurnal Pekommas, Vol. 18, No. 3, Hlm. 204

Sari, Dina. P. (2020). Kreativitas Dosen Sebagai Youtuber Pada New Normal. Jurnal Akrab Juara, 5(3), 183-195.

Sucipto, S., \& Istiqomah, S. (2020). Upaya Penguatan Kapabilitas Masyarakat Dalam Pengenalan Perilaku Hidup Bersih dan Sehat (PHBS) di Era New Normal. Transformatif: Jurnal Pengabdian Masyarakat, 1(2). 